\title{
Zika Virus Infection, Summer Olympic and Paralympic Games in Rio 2016, and Sports Performance
}

\author{
by \\ Rodrigo Luiz Vancini ${ }^{1}$, Marília Santos Andrade², \\ Cássia Regina Vancini-Campanharo ${ }^{3}$, Claudio Andre Barbosa de Lira ${ }^{4}$
}

\section{Dear Editor,}

Viral diseases in competitive athletes have attracted considerable interest. The environments in which these athletes compete, their training and travel involved provide numerous opportunities for diseases transmission and infection (Turbeville et al., 2006). Ximenes et al. (2016) proposed a mathematical model to calculate the risk of dengue acquisition by foreign tourists at the Olympic Games in Rio 2016 and concluded that if dengue returned in 2016 with the same pattern observed in August 2007, the incidence of symptomatic and asymptomatic cases among tourists would be 5.75 and 51.5 per 100,000 individuals, respectively.

Zika disease, transmitted by the same mosquito (Aedes aegypti) as dengue, has become a public health issue, drawing the attention of the scientific and sports community as well as the World Health Organization due to its rapid propagation. Brazil has been of a particular focus given the upcoming 2016 Summer Olympic and Paralympic Games in Rio (Petersen, 2016; WHO, 2016). Pau Gasol, an NBA basketball player previously enrolled in a medical school before pursuing a sports career, is considering not attending the Olympic Games in Rio 2016 due to Zika disease. He pointed out that athletes needed more information before taking a decision because their health is at risk (The Guardian, 2016). Serena Williams, the top-ranked female tennis player in the world, has also voiced concerns about the Zika virus and plans to take multiple precautions while taking part in the Games (The Washington Post, 2016).

Zika disease is caused by a ribonucleic acid (RNA) virus, specifically, Aedes mosquito-borne flavivirus. It is an undifferentiated systemic febrile illness and its acute clinical presentation can include headache, fatigue, myalgia (muscle pain), arthralgia (joint pain), asthenia (weakness), edema in the lower limbs, anorexia (reduced appetite) and gastrointestinal disturbances (vomiting, diarrhea and abdominal pain) (Waggoner and Pinsky, 2016).

Diagnostic confirmation of Zika fever includes viral culture, antibody, antigen and RNA detection (Waggoner and Pinsky, 2016). However, clinical diagnosis may be inconclusive and confounded with other diseases and conditions such as Dengue and Chikungunya (Pinto Junior et al., 2015).

There are no vaccines or specific antiviral drugs for treating the disease. The use of analgesics and antipyretics should be prescribed with care to avoid adverse effects such as hepatopathy, nephropathy and allergies. The use of salicylates (aspirin) should be discouraged to prevent internal bleeding in wrongly diagnosed individuals (Pinto Junior et al., 2015).

\footnotetext{
1 - Centro de Educação Física e Desportos (CEFD), Universidade Federal do Espírito Santo (UFES), Espírito Santo (ES), Brasil.

2 - Departamento de Fisiologia, Universidade Federal de Säo Paulo (UNIFESP), São Paulo (SP), Brasil.

3 - Escola Paulista de Enfermagem, Universidade Federal de São Paulo (UNIFESP), São Paulo (SP), Brasil.

4 - Setor de Fisiologia Humana e do Exercício, Faculdade de Educação Física e Dança, Universidade Federal de Goiás (UFG), Goiânia, Goiás (GO), Brasil.
} 
Although no relevant data is available in the literature, we may hypothesize that reported symptoms of Zika fever potentially impair sport performance as a result of muscle impairment. In dengue infection, which has similar symptoms to Zika disease, Kalita et al. (2012) evaluated the muscle involvement and damage in 13 patients. Muscle biopsy revealed interstitial hemorrhage without inflammation or vasculitis (inflammation of blood vessels) with a median creatine kinase level of $480 \mathrm{U} / \mathrm{L}(300-2,477) \mathrm{U} / \mathrm{L}$. Also, Misra et al. (2012) evaluated 39 patients with dengue of whom 31 showed evidence of muscle impairment (clinical and subclinical symptoms), eight had severe weakness and five hyporeflexia (reduced or absence of reflexes). Recently, Brasil et al. (2016) evaluated 364 suspected cases of Zika in the state of Rio de Janeiro based on clinical diagnosis. Of these cases, 71.9\% (262) were tested (by Zika virus RNA detection) and 45.4\% (119) had a confirmed diagnosis of the disease. It is important to point out that over $50 \%$ of the patients reported muscle impairment.

Given that mega sporting and mass events put people at risk of acquiring infectious diseases (Petersen, 2016), promoting protection strategies and dissemination of accurate information may be necessary to prevent disease infection among athletes. Strategies such as air conditioning in the Olympic Village bedrooms, use of insect repellents, protective clothing and insecticide-treated mosquito nets should be used (WHO, 2016; Ross, 2016) to ensure that athletes optimize their performance and experience at the Rio 2016 Olympic and Paralympic Games.

The authors declare that they have no conflicts of interest in the authorship and publication of this contribution. English review of this manuscript was carried out by a native English speaker and was supported by Fundação de Amparo à Pesquisa do Estado de Goiás (FAPEG, Chamada no. 10/2013, CAPES-Programa de Apoio à Pós-Graduação-PPGS-FAPEG).

\section{References}

Brasil P, Calvet GA, Siqueira AM, Wakimoto M, de Sequeira PC, Nobre A, Quintana Mde S, Mendonça MC, Lupi O, de Souza RV, Romero C, Zogbi H, Bressan Cda S, Alves SS, Lourenço-de-Oliveira R, Nogueira RM, Carvalho MS, de Filippis AM, Jaenisch T. Zika Virus Outbreak in Rio de Janeiro, Brazil: Clinical Characterization, Epidemiological and Virological Aspects. PLoS Negl Trop Dis, 2016; 10: e0004636

Kalita J, Misra UK, Maurya PK, Shankar SK, Mahadevan A. Quantitative electromyography in dengueassociated muscle dysfunction. J Clin Neurophysiol, 2012; 29: 468-471

Misra UK, Kalita J, Maurya PK, Kumar P, Shankar SK, Mahadevan A. Dengue-associated transient muscle dysfunction: clinical, electromyography and histopathological changes. Infection, 2012; 40: 125-130

Petersen E, Wilson ME, Touch S, McCloskey B, Mwaba P, Bates M, Dar O, Mattes F, Kidd M, Ippolito G, Azhar EI, Zumla A. Rapid Spread of Zika Virus in The Americas - Implications for Public Health Preparedness for Mass Gatherings at the 2016 Brazil Olympic Games. Int J Infect Dis, 2016; 44: 11-15

Pinto Junior VL, Luz K, Parreira R, Ferrinho P. Zika Virus: A Review to Clinicians. Acta Med Port, 2015; 28: $760-765$

Ross J. What you need to know about Zika virus, 2016. Available at: http://www.health.harvard.edu/blog/what-you-need-to-know-about-zika-virus-201602019114; accessed on 03.03.2016

The Guardian. NBA star Pau Gasol considers skipping Olympics due to Zika virus concerns, 2016. Available at:https://www.theguardian.com/sport/2016/may/30/pau-gasol-zika-virus-olympics-rio-brazil; accessed on 31.05.2016

The Washington Post. Venus Williams says she's "not an expert" on Zika virus, so she's staying mum, 2016. Available at: https://www.washingtonpost.com/news/early-lead/wp/2016/05/28/venus-williams-saysshes-not-an-expert-on-zika-virus-so-shes-staying-mum/; accessed on 01.06.2016

Turbeville SD, Cowan LD, Greenfield RA. Infectious disease outbreaks in competitive sports: a review of the literature. Am J Sports Med, 2006; 34: 1860-1865

Waggoner JJ, Pinsky BA. Zika Virus: Diagnostics for an Emerging Pandemic Threat. J Clin Microbiol, 2016; 54: 
860-867

World Health Organization (WHO): Zika Situation Report. Zika and Potential Complications, 12 February 2016. Available at: http://www.who.int/emergencies/zika-virus/situation-report/who-zika-situationreport-12-02-2016.pdf; accessed on 12.02.2016

Ximenes R, Amaku M, Lopez LF, Coutinho FA, Burattini MN, Greenhalgh D, Wilder-Smith A, Struchiner CJ, Massad E. The risk of dengue for non-immune foreign visitors to the 2016 Summer Olympic Games in Rio de Janeiro, Brazil. BMC Infect Dis, 2016; 16: 186

\section{Corresponding author:}

\section{Claudio Andre Barbosa de Lira}

Universidade Federal de Goiás

Faculdade de Educação Física e Dança - Setor de Fisiologia Humana e do Exercício; Avenida Esperança s/n, Campus Samambaia, Goiânia (GO), CEP: 74690-900, Brazil

Phone: +55-62-3521-1141

E-mail: andre.claudio@gmail.com 